Original scientific paper

Received: 26.09.2016.

Approved: 25.11.2016.

\title{
THE RISE AND GROWTH \\ OF SERBIAN BANKING UNTIL WORLD WAR I** \\ Part One: \\ Creation of preconditions for the rise \\ of Serbian banking until 1878
}

The development of Serbian banking during the $19^{\text {th }}$ century was a gradual process that underwent two distinctive stages with the turning point in 1878 when Serbia became an independent state by the international agreement concluded at the Berlin Peace Conference. In the first stage, until 1878, the vassal state of Serbia had been introducing necessary political, economic and institutional preconditions for the rise of banking that led to the creation of the first organized credits and banks. At the end of this stage, there were two types of proper banks: state banks and privately-owned banks. Since the authorities of the vassal state of Serbia played a key role in preparing institutional framework for the banking operations and in organizing the first credit facilities, it could be argued that Serbian banking arose in the $19^{\text {th }}$ century as a result of both state-backed and growthinduced processes.

Keywords: banking, organized credits, interest rates, usury, paid-up capital, the vassal state of Serbia

* PhD, Biljana Stojanović, Full-time Professor of the Faculty of Geoeconomics (Former Faculty of International Economics), John Naisbitt University, Belgrade, Serbia, bstojanovic@naisbitt.edu.rs

** This paper was prepared and presented in English language on XV World Economic History Congress, held in Utrecht, the Netherlands, from 3 to 7 August, 2009. 
Biljana Stojanović

\section{Introduction}

The main subject of the analysis in this paper is the development of Serbian banking on the territories of Belgrade Pashaluk, vassal Principality of Serbia and Kingdom of Serbia from the beginning of the $19^{\text {th }}$ century until the First World War.

The late nineteenth century was a national banking era for many countries in the world. For those countries that had already been sovereign states, like the USA and Japan, there was the ongoing process of comprehensive bank reforms aiming at shaping more congruent and efficient banking systems conducive to stability and the growth of the national economy, particularly the industry. ${ }^{1}$ On the other hand, for Serbia, which gained political independence at the Berlin Peace Conference in 1878, it was an era of the inception of the national banking system.

Prior to 1878, the government of the vassal state of Serbia had been making efforts in introducing new legislative measures that would enable economic transition from feudal to capitalistic economic system. Also, those efforts included organizing credit facilities from the public funds. In time, however, simultaneously to favorable institutional and economic framework, arose private initiatives in the business of banking. Thus, during vassalage, the political, economic and institutional preconditions had been unfolding that led to the creation of the first banks in 1860's and 1870's. This rudimentary stage of banking evolved into a full-fledged national banking with the formation of the independent Principality of Serbia in 1878 that was to be proclaimed Kingdom in 1882 .

The basic structure of the banking system in the Kingdom of Serbia, more or less, followed the pattern of the banking systems in Europe with the Privileged National Bank of the Kingdom of Serbia (the National Bank) as a national bank of note-issue (developing into a proper central bank), and the host of other banks (and bank-like institutions) of various sizes and types of ownership.

Up to the present day, the Serbian economic literature has quite extensively elucidated the work and operations of the National Bank until the World War I. Ample official records facilitated these surveys too. On the other hand, data on the operations and work of the other banks are scattered and less reliable which makes a comprehensive analysis of their operations rather a difficult task. Having this general limitation, and relying mostly on the available official statistics, this paper tries to shed more light on the rise and growth of the banks in Serbia from the beginning of the $19^{\text {th }}$ century until the World War I.

The first part of the paper deals with the initial stage of the rise of banking that took place until 1878, showing how gradually preconditions of banking were unfolding, how vassal state of Serbia was active in organizing credit facilities and

For the USA in: White, E. (1998): Were Banks special Intermediaries in Late Nineteenth Century America, Federal Reserve Bank of St. Louis, May/June. For Japan in: Cameron, R et.al.,(1967): Banking in the Early Stages of Industrialization, Oxford University Press, London. 
how the first state credit institutions and private banks were set up and operated. The second part of the paper deals with the growth of banking of the independent state of Serbia. In this part, all the major quantitative and qualitative aspects of banking are analyzed - its structure, the rate of expansion, size, the factors of growth and the importance of banking for the economy is evaluated. The third part deals with relations of the National Bank with the other banks trying to discover in what extent the National Bank succeeded to perform the classical function of the central bank - the role of the lender of the last resort.

\section{The Medieval Beginnings}

The history of Serbian banking actually begins in the late medieval times like in many other European countries. Durung $13^{\text {th }}, 14^{\text {th }}$ and $15^{\text {th }}$ centuries, especially famous throughout Europe were private bankers from Italian citystates - Venice, Florence, Genoa and Milan. ${ }^{2}$

During the reign of Emperor Dušan (1331-1355), lending money, i.e. giving money on interest, was considered as an independent profession in Serbia. A lender was known as "kamatnik" which comes from the word "kamata" meaning "interest". It is important to note here, that in medieval Serbia paying interest for the loan was considered as an acceptable practice, i.e. interest was taken as a price for money. This was in contrast with many European countries where the interest was banned under the influence of the Catholic Church's dogma that every interest was a form of usury. Nonetheless, in practice this ban was not obeyed.

In Serbian medieval written documents there were no other bans regarding credit operations except one - the lender could be anyone but the monk. ${ }^{4}$ Loans were made in coined money - first in foreign, and with the coinage of the Serbian silver dinar from the late $13^{\text {th }}$ century, loans were transacted in domestic coins respectively. It was a regular custom that loans were secured with some kind of a pledge - jewelry and other movable valuables, land or sovereign's revenues (in case of the King or Emperor being a borrower). Exceptionally rarely, loans were issued without the pledge. It was interesting that the pledge was not defined to protect only the interest of the lender, but also the interest of the borrower since, according to Article 90 of the Emperor Dušan's Law, the borrower could repurchase the pledge at any time, i.e. even if he missed to meet the originally contracted deadline of a loan. ${ }^{5}$

2 Kindleberger, P. Charles, (1987) A Financial History of Western Europe, George Allen \&Unvin, London, 41.

3 Gnjatović, D., Dugalić, V., Stojanović, B. (2003): Istorija nacionalnog novca, Sineks, Beograd, 101.

Ibid.

Taranovski, Teodor (2002): Istorija srpskog prava u Nemanjićkoj državi, Lirika, d.o.o, Beograd, 494. 
These secured loans were in widespread use in medieval Serbia from the beginning of the $14^{\text {th }}$ century.

Apart from lending, other banking businesses were also practiced in medieval Serbia. Written sources from the second half of the $14^{\text {th }}$ century mention cases of taking deposits with paying interest as an established banking business.

Medieval Serbia had highly prosperous economy during the first half of the $15^{\text {th }}$ century. Economic prosperity was the result of the comprehensive economic, political and diplomatic measures taken by the mighty figure of the Serbian ruler Despot Stefan Lazarević (1395-1427) - perhaps the greatest Serbian statesmen of all times. ${ }^{6}$ Apart from the traditional agriculture, mining, domestic and foreign trade (particularly export of silver) were especially flourishing during his reign, in spite of him being a double vassal - Turkish and Hungarian. The external factor contributing to this prosperity was the bullion famine that prevailed throughout Europe during $15^{\text {th }}$ century. The reasons for the bullion famine lay, on the one hand, in the depletion of principal European silver mines (located in today's Germany, Austria, The Czech Republic and Slovakia) and, on the other hand, in persistent huge European trade deficit with countries of the Far East - China and India. ${ }^{7}$ The diminished European silver production caused severe monetary problems since the silver was the main monetary metal in Europe. Mints closed down and consequently production of silver coins had dropped all across Europe, causing shortage of money, debasement and deflation of prices.

This grave situation in Europe was, however, favorable for medieval Serbia. Its rich silver mines increased production and export of silver during the first half of the $15^{\text {th }}$ century. According to some estimates, Serbian export of silver only to Dubrovnik in the period 1427-32 was around 25 tons a year. ${ }^{8}$ This suggests that Serbia was one of the primary producers and suppliers of silver to the European market. While many European countries at that time of bullion famine faced depreciation, i.e. debasement of their currencies, Serbia experienced revaluation of its currency - silver dinar. As early as 1407, Despot Stefan Lazarević increased the weight of his silver dinar from the average weight of 0,30-0,43 grams to $0,82-1,2$ grams. ${ }^{9}$ The weight was maintained for almost another 50 years when it dropped to only 0,34 grams due to the state's financial needs caused by the wars with Turks. ${ }^{10}$

All these economic and monetary developments that stimulated banking activities were abruptly interrupted in 1459, when Serbia fell under the rule of

$\overline{6} \quad$ Kalić, J.(2001): Srbi u poznom srednjem veku, Službeni list SRJ, Beograd, 98-108.

7 Allen, Larry (2009): The Encyclopedia of Money, Second edition, ABC Santa Barbara, California; Denver, Colorado; Oxford, England, 188.

8 Tadić, J. (1968): Privreda Dubrovnika i srpske zemlje u prvoj polovini XV veka, Zbornik filozofskog fakulteta, X-1, 531.

9 Stojaković, Slobodanka (2006): Despot Stefan Lazarević, Srpsko numuzmatičko društvo, Beograd, str. 158.

10 Petrović, J., (1933-34): Veoma retki srpski srednjovekovni grošići iz sela Malo Boljince kod Vlasotinaca, Starinar VIII-IX, str. 24. 
the Ottoman Empire which introduced its own feudal economic and monetary systems. Coming under the monetary sovereignty of the central monetary authority in Istanbul, Serbia lost the right to coin its silver dinar. Serbian people left towns and moved inland far away from the main routes, living mainly on cattle raising in closed patriarchal family units. Economic life in these selfsufficient units diminished the need for money since exchange reverted to barter. Trade fell exclusively in the hands of Turks, Tzintzars and Greek merchants. Under such circumstances Serbian medieval banking lost chances to grow for almost another four centuries.

\section{Building the Political, Economic and Institutional Preconditions until 1878}

In the process of step by step liberation from the Ottoman rule that was intensified from the beginning of the 19th century, the possibilities for Serbian economic and monetary developments were reopened and led to creating first banks in 1860 s and 1870 s. The Serbian rule was developing rather slowly by gaining from Porta (the Ottoman Government) one by one various autonomous legal and economic rights. Among the first autonomous rights, central to financial development, was the right to collect taxes, granted to the Serbian Prince and the elders in 1815.

From the beginning of the $19^{\text {th }}$ century until World War I, the territory of Serbia had enlarged and its population had increased. The enlargement of the territory is shown on the Figure 1 in Appendix.

Parallel with gaining autonomous rights in negotiations with Ottoman empire, Serbian ruler, Prince Miloš (1780-1860), introduced active policy of colonization, i.e. immigration of Serbian people from other countries, particularly from Austria. This led to the increase of population between 1815 and 1839 . After 1839, population growth still continued by immigration, but also by the natural increase, so that between 1834 and 1874 population had almost doubled - from 0,678 to 1,353 million (Table 1 ).

A large number of immigrants were craftsmen and merchants mostly settled in towns, who were contributing to the revival of production and trade and causing economic change, modernization and consequently development of credit activities. Nevertheless, in 1874 the share of town population reached only $10 \%$ and that of the capital of Serbia, Belgrade, only 2\% (Figure 1) of the total Serbian population. This meant that the majority of population were peasants and that agriculture was the main branch of the economy. 
Table 1. Population of the Principality of Serbia 1834-1874

\begin{tabular}{|c|c|c|c|c|c|}
\hline Year & Total & \multicolumn{1}{|c|}{ Towns } & Belgrade & $\begin{array}{c}\text { Towns } \\
\text { in \% of total }\end{array}$ & $\begin{array}{c}\text { Belgrade } \\
\text { in \% of total }\end{array}$ \\
\hline 1834 & 678192 & 41347 & 7033 & 6,0 & 1,0 \\
\hline 1841 & 828895 & - & - & - & - \\
\hline 1846 & 915000 & - & 14371 & - & 1,5 \\
\hline 1850 & 956893 & - & 12344 & - & 1,3 \\
\hline 1854 & 998919 & - & 14600 & - & 1,4 \\
\hline 1859 & 1078281 & 86841 & 18860 & 8,0 & 1,7 \\
\hline 1863 & 1108668 & 97692 & 14760 & 9,0 & 1,3 \\
\hline 1866 & 1216342 & 116007 & 24768 & 10,0 & 2,0 \\
\hline 1874 & 1353890 & 138710 & 27605 & 10,0 & 2,0 \\
\hline
\end{tabular}

Source: Statistički godišnjak Kraljevine Srbije, various years.

Figure 1. Share of Belgrade and other towns in total population

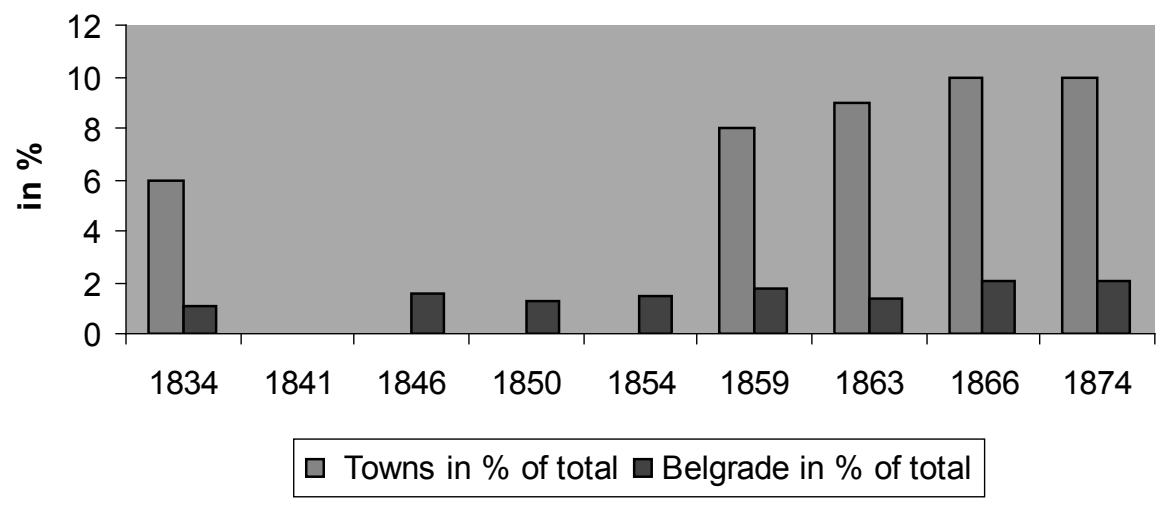

Source: Table 1

Even in spite of this, the earliest proposals for the creation of banks appeared in 1808. They weren't caused by the increasing demand for money and credit from the rising business community, but by the need to finance the purchase of weapons and other war materials as advocated by the Serbian wealthier elders during the First Uprising (1804-13) against the Ottoman rule. ${ }^{11}$ The banks had not been created and this need was partly financed by clandestine minting of silver Turkish and Austrian copper coins. ${ }^{12}$ Since they did not much differ from the original ones, these coins were successfully put into circulation. ${ }^{13}$

\footnotetext{
11 Milić, D. (1998): Privredne prilike u Srbiji na početku XIX veka, Zbornik, Narodni muzej Niš, broj 5, Niš, 26.

12 Milić, D. (1959): Trgovina Srbije 1815-1839, Nolit, Beograd, 21.

$13 \quad$ Ibid. 30.
} 
In the period between 1815 and 1830, cattle trade was an economic activity that gave an impetus to the revival of overall economic life, including credit operations. The main export market was Austria. Serbian cattle merchants were small merchants who lacked money and capital. They conducted their trade with the help of commercial credits, known as "veresija", in their relations with the Austrian partners. Having overcome successfully this obstacle of shortage of money and capital by commercial credits, they faced another obstacle - monopolistic power of Prince Miloš who concentrated in his hands, not only political, but economic power as well. Prince Miloš thus became the major impediment for unfettered growth of foreign and domestic trade. He controlled trade by a wide range of direct and indirect instruments - prohibitions, licenses, price controls, regulations on trade fairs and credit relations between the merchants. ${ }^{14}$

To restrict competition from other Serbian merchants, in order to secure his monopolistic position, Prince Miloš forbade the use of commercial credits in the cattle exports to Austria, which severely affected the majority of small merchants. The use of commercial credit was also banned in the internal trade. In practice, however, this ban was not obeyed since commercial credit was of crucial importance for smoothly conducting foreign and domestic trade, so the merchants continued to use it regardless of the ban.

From the above mentioned, it could be argued that commercial credit or "veresija" marked the beginning of credit operations in Ottoman-ruled Serbia in the first half of the $19^{\text {th }}$ century.

Apart from resorting to "veresija", Serbian small merchants developed the practice of forming partnerships between themselves as a method of overcoming the shortage of money and capital. The partnership was known as "ortakluk". Usually, one partnership numbered from two to ten individuals. The latter was commonly known as trade company.

The partnerships were widespread, not only among merchants but between them, craftsmen and other businessmen. It was not rarely the case that one merchant was a party in several different partnerships. The use of commercial credits in partnerships led to the formation of the network of overlapping credit relations between the parties that very often ended up in disputes.

The partnerships that spontaneously arose in this period were the embryo of joint-stock companies of the later date.

The monopolistic position of Prince Miloš and his close partners (family members, friends and state officials) hindered the development of trade and credit, but only temporarily. In 1820, there were 56 big exporters while, by the year of 1836, there were 7913 people whose main line of work was trade and craft. ${ }^{15}$

Beside the monopolistic power of the Prince Miloš, yet another impediment to the growth of trade was the chaotic monetary system with 43 Turkish and for-

$14 \quad$ Ibid. 104.

$15 \quad$ Ibid. 124 and 197. 
eign kinds of money in circulation - 10 golden, 28 silver and 5 cooper. ${ }^{16}$ To facilitate payments, the Serbian authorities issued currency exchange rate lists. These lists determined exchange rates, i.e. the prices of Turkish and foreign currencies in Serbian accounting unit called "groš" (grosh). The groš itself had been introduced much earlier, in the period of the Austrian occupation of Serbia from 1717 to $1739 .{ }^{17}$

The Hatisherifs of 1830 and 1833 granted Serbia relatively wide internal autonomy by which it formally became a vassal principality of the Ottoman Empire under the Russian protectorate. ${ }^{18}$ Soon after, in 1838, another Hatisherif was issued defining the internal state order in Serbia and regulating other social and economic issues. This Hatisherif is known as the "Turkish Constitution" of Serbia (since the Serbian one declared in 1835 had been abolished).

Framed by the provisions of Hatisherifs, Serbian authorities carried out various internal economic and legislative measures that enabled transition from barter to market economy, higher monetization of the economy and adopted legal regulations of the economic activities and business organizations.

The most important of these measures were: abolition of the Turkish feudal system in Serbia $(1833,1835)$, introduction of tax collection in money terms (1835), granting of unlimited landowner rights to Serbian peasants (1839) ${ }^{19}$ and adoption of free trade principle.

The adoption and application of free trade had two phases. In the first, Porta granted freedom to Serbian people to conduct trade across the whole territory of the Ottoman Empire (1830). In the second, Serbian authorities began to loosen internal trade restrictions imposed by the Prince Miloš. Officially, this phase began with the provision on free trade granted by 1838 Constitution (Article 45). In practice, this phase began in 1839 by the state Decree allowing free opening of private retail shops in the Serbian villages that Prince Miloš had forbidden previously. $^{20}$

Regarding legislation, two acts were of particular significance for economic and credit issues - the Civil Code of 1844 and the Commercial Act of 1860. The Civil Code acknowledged full unlimited private property rights to all Serbian citizens (Chapter III), regulated credit relations (Chapter XXI) and defined partnerships (Chapter XXVII) in general terms. ${ }^{21}$ Provisions of the Commercial Act

$16 \quad$ Ibid. 251.

17 Dugalić, V. (1999): Narodna banka 1884-1941, Jugoslovenski pregled, Beograd, 15.

18 The Russian protectorate lasted until the Paris Peace Treaty of 1856, when the protectorate was transferred to England, France and Sardinia.This way Serbian autonomy was granted international recognition. (Stanojević, S. (2008): Istorija srpskog naroda, Logos Art, Beograd, 300).

19 Vučo, Dr N. (1955): Privredna istorija Srbije, Naučna knjiga, Beograd, 169.

20 Milić, D. (1959), 150.

21 Građanski zakonik za Kraljevinu Srbiju, (1891), u Beogradu, štampa i izdanje Kralj.srpske drž. Štamparije. 
more comprehensively regulated trade and types of partnerships - offering possibilities for creating three forms of partnerships (Chapter III): public (unlimited), mixed (with limited liability) and joint-stock (limited liability). ${ }^{22}$

\section{The First Organized Credits}

Gradual enlargement of the territory, increase of population, building of autonomous economic and institutional framework, together with the growth of internal and foreign trade, resulted in steady increase in demand for money and credits in the vassal Principality of Serbia.

As already indicated, this demand was initially met by commercial credits known as "veresija". However, the loans in coined money were very rare. Only a small number of wealthy merchants, at first foreign and later Serbian, was able to give such loans. The principal cash creditor was Prince Miloš. ${ }^{23}$ His debtors were Serbian merchants and higher civil servants but also Turks and other foreigners. In the course of time, a new class of small shopkeepers and owners of taverns joined the group of cash creditors.

In negotiating a loan, every creditor determined the level of interest rate according to his opinion of the debtor's creditworthiness. Because of the absence of any credit regulations and big demand for money and credit, there was a tendency of contracting very high interest rates that reached usurious levels - from $24 \%$ to $50 \%$ a year. ${ }^{24}$ It was not rare that the interest very often exceeded the principal, with the interest rate rocketing to even $120 \%$ a year. ${ }^{25}$

The practice of usury began to ruin Serbian peasants. They found themselves in a paradoxical position - legally, they had become free from the shackles of feudal system and unlimited owners of their land, but in practice they were caught in the net of their greedy creditors. To prevent the total ruin of farmers, Prince Miloš issued a decree in 1836 that proscribed a minimum of land (known as "baština") with the house and cattle (two oxen and a cow) that a peasant could not pledge for a loan. Subsequently, the minimum of protected land was defined to be 0,8 hectares $(1861)^{26}$ and to be 2,875 hectares $(1873) .{ }^{27}$ In the beginning these legal regulations protected peasants from usury, but in the long-run, they had two unfavorable consequences: first, Serbia was constricted to having small farm

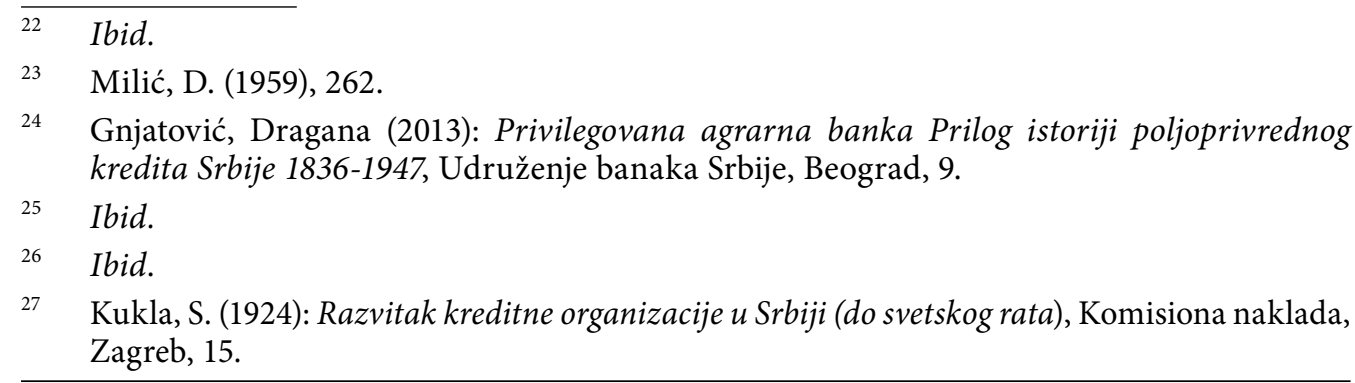


estates, second, the development of mortgage loans to the Serbian peasants was hampered. Unfortunately, these legal limitations of developing mortgage loans for agriculture were in force throughout the life of the Kingdom of Serbia and were abolished with the establishment of Priviliged agrarian bank in 1929. ${ }^{28}$

In order to alleviate the shortage of cash loans, Prince Miloš began to advance such loans from the state treasury reserves that were accumulated as a result of the continuous fiscal surpluses starting from $1822 .{ }^{29}$ The state reserves were physically kept in special iron crates for which reason they were called the "immovable crate". ${ }^{30}$ The loans from reserves were advanced with or without interest and security for the repayment of the loan, depending on the borrower.

To meet the growing demand for money and credit, in 1836 the Serbian state began with the practice of allowing certain public funds to be sources for cash credits. The first such funds were the church and orphan funds. ${ }^{31}$ Until 1856, other public funds also became the sources of credits - court, widow, communal and school funds. Maturity of these credits were three years with the $6 \%$ interest rates. ${ }^{32}$

In 1837, the total amount of loans advanced from the state reserves to individuals, local authorities and monasteries was 103.029 ducats of which half yielded interest. ${ }^{33}$ The same year, Prince Miloš proscribed annual maximum interest rate of $12 \%$ in credit operations as another measure against expanding usury. ${ }^{34}$ From 1838 , loans from the state reserves started to be given to wealthier farmers. ${ }^{35}$

To improve credit organization further, the vassal state of Serbia adopted two important measures in 1839. The first was the establishment of the institution of the State Banker and the second was adoption of Regulation for the Loan from the State Treasury.

The State Banker was authorized to effect international payments and contract foreign loans on behalf of the Serbian state. Customarily, only well-established Serbian merchants were appointed to the post. A foreign banker Tirka from Vienna was an exception in this regard. ${ }^{36}$ Officially, they were paid commission for their work but actually they took advantage of their position to gain huge

$\overline{28}$ Gnjatović, Dragana, (2013), 7.

29 Petrović, M. (1901): Finansije i ustanove obnovljene Srbije do 1842, knjiga I, Štampano u državnoj štampariji Kraljevine Srbije, 359.

30 Milić, D. (1981): Nepokretna kasa, Istorijski institut, Poseban otisak iz mešovite građe, Knjiga 9, Beograd.

31 Glomazić, M. (1933): Istorija državne hipotekarne banke 1862-1932, Narodna misao, Beograd, 53.

32 Gnjatović, Dragana, (2013), 9.

33 Cvijetić, L. (1970): Kreditiranje iz državne kase do formiranja Uprave fondova, Finansije XXV, broj 9-10, 500.

34 Arhiv Srbije, (1837): Zbornik zakona, Zbornik 30, Beograd, 137.

35 Petrović, M. (1901), 395.

36 Cvijetić, L. (1965): Pokušaji osnivanja prvih banaka u Srbiji, Finansije broj 1-2, 119. 
profits for their own pockets. It is recorded, for example, that the State Banker Jovan Kumanudi used to raise loans in Vienna with normal market interest rates in order to give loans to Serbian borrowers with usurious interest rates. ${ }^{37}$

Regulation for the Loan from the State Treasury (Regulation) was the first official act that regulated credit operations in the vassal state of Serbia. According to Regulation, credit must be secured by immovable property, annual interest rate was $6 \%$, minimum amount of loan was 50 ducats but the maximum amount was not limited. Maturities were not determined but the possibility of prolonging agreed maturities was allowed. In a year, however, the minimum amount was changed to be 300 ducats. Because of this change, small borrowers, who were the most needy and numerous, were practically excluded from the access to the state treasury and again left to usury. Thus, the "immovable crate" remained open to wealthy merchants and higher state officials. They borrowed from it at $6 \%$ interest and then re-loaned the same money to small borrowers at usurious interest.

During the regime of Constitution Defenders (1842-1858), usurious interest rates soared to $300 \%$ and bankruptcies of small businessmen and farmers were widespread. ${ }^{38}$ Despite this, the regime did almost nothing for economic development and improvement of credit organization. ${ }^{39}$ Various proposals to create a note-issuing bank in the form of joint-stock company together with other types of banks were rejected by the regime. To make things worse, the regime produced permanent fiscal deficits which were covered from the state reserves, i.e. the "immovable crate", from which cash loans were also advanced to the public. All this led to a drastic decrease of cash in the "immovable crate". From the previous 380000 ducats, cash in the state reserves shrank to only 25000 ducats. At the same time, debt instruments (bonds) rose to 266000 ducats before the end of the regime.

The decline of the cash in the state reserves forced the Ministry of Finance to announce in 1858 that the proposal of setting up state note-issuing bank should be abandoned simply because the State did not have sufficient metal cover for such a bank. Instead, the Ministry proposed creation of a private note-issuing bank under the state control. ${ }^{40}$

One of the greatest debtors of the "immovable crate" during 1850s was Porta, the Turkish central government that was regarded as a privileged borrower. As an illustration, in 1856, Porta got a loan of 90909 ducats with maturity of seven years without obligation to pay interest. ${ }^{41}$ Porta used the loan to finance the con-

37 Cvijetić, Dr L. (1970): Kreditiranje iz državne kase do formiranja Uprave fondova, Finansije XXV, broj 9-10, 508.

$38 \quad$ Ibid. 504.

39 Jovanović, Slobodan (1925): Ustavobranitelji i njihova vlada (1838-1858), drugo dopunjeno izdanje, Izdavačka knjižarnica Napredak, Beograd, 87.

$40 \quad$ Dugalić, V. (1999), 26.

41 Cvijetić, Dr L. (1970), 510

Vol. 13, № 3 2016: 1-20 
struction of telegraphic line between the Turkish town of Jedrene and Serbian Niš. The State Banker Jovan Kumanudi escorted transportation of the precious freight to Istanbul on the Serbian treasury's account.

\section{The First Banks}

Credit operations from the state reserves were abolished in 1860 by Prince Miloš, who once again came to power and who had originally begun with these operations in 1836. With this decision, however, Serbian state did not give up credit organization but resorted to other institutional forms to promote credit facilities.

From 1862, several state and private banks were founded:

1) Administration of Funds, 1862, Belgrade

2) The First Serbian Bank, 1869, Belgrade

3) District Savings Houses, 1871, Kragujevac, Užice, Kruševac, Čačak, and Smederevo

4) Belgrade Credit House 1871, Belgrade

5) Smederevo Credit Bank, 1871, Smederevo

6) Valjevo Savings House 1871, Valjevo

7) The Bank of Požarevac, 1871, Požarevac

8) Serbian Danube Bank, 1873, Svilajnac

The State decided in 1862 to unite previously separated public and court funds into one fund under the name of Administration of Funds that became an autonomous department of the Ministry of Finance. At that time, the total debt to these funds reached 978.000 ducats. ${ }^{42}$

The Administration of Funds was established with the main purpose to give long-term mortgage loans with $6 \%$ annual interest primarily for farming and other peasants' needs. The State guaranteed for its operations. As a compensation for the state support, a part of interest proceeds and the whole profit of the Administration of Funds went to the state treasury.

Although the Administration of Funds was not a completely independent financial institution, it could be considered as a forerunner of the proper mortgage bank into which it was gradually transformed. The first act that gave it the character of a proper mortgage bank was the Act on Debentures of the Administration of Funds passed in 1864 that allowed this institution to issue mortgage debentures. ${ }^{43}$

From the start, the bulk of loans from the Administration of Funds went to borrowers from the capital of Belgrade - about 51\%, and other towns - 36\%.

42 Milić, Dr D., (1994): Monetarno-kreditni sistem u privredi Srbije početkom XX veka, in: Srbija u modernizacijskim procesima XX veka, Institut za noviju istoriju, Srbije, Beograd, 81.

43 Glomazić, M. (1933), 61. 
Only $13 \%$ went to peasants who represented $91 \%$ of the total population. Among other factors, to the small peasants' share contributed the defined legal minimum of 2,875 hectares that could not be pledged for a loan because $21 \%$ of all farmers' estates were less than 2 hectares. Other 33\% of farmers' estates were between 2 and 5 hectares and 7\% were between 5 and 10 hectares. ${ }^{44}$

With an idea to create financial institution that is more appropriately adjusted to the peasants' needs, the state set up five District Savings Houses in 1871. The financial potential of District Savings Houses were created mainly by transferring funds from the Administration of Funds. This lowered total financial potential of the Administration of Funds. To strengthen financial resources of the Administration of Funds, a new act on mortgage debentures was passed in 1874 that allowed the Administration of Funds to mobilize additional capital by issuing state guaranteed mortgage debentures. ${ }^{45}$

The District Savings Houses were authorized to give loans only within their own territories with maturities ranging from six months to three years at annual interest rate of $7 \%{ }^{46}$ In the Article 15 of the Act on District Savings Houses, it is explicitly emphasized that farmers had priority rights for borrowing from savings houses. The loans advanced to individuals were secured by immovable property or, rather exceptionally, by municipal guarantees. Local authorities were allowed to raise loans at savings houses but only by issuing bonds. The minimum amount of the loan for individuals, i.e. physical persons was determined at 5 and maximum at 500 ducats but local authorities could raise much higher amounts ${ }^{47}$. To strengthen their credit potential, District Savings Houses were allowed to take private deposits at $5 \%$ and $3 \%$ interest rates annually. From the interest proceeds, District Saving Houses had to pay a sum to the state treasury as a compensation for the state guarantee.

\section{The First Serbian Bank - establishment and downfall}

Having established relations with foreign banks, especially from Vienna and Budapest, Serbian merchants were very active in making proposals for the creation of Serbian national note-issuing bank. Since the realization of these proposals were being procrastinated, as already mentioned, one group of Serbian merchants, led by the State Banker Živko Karabiberović, established the First Serbian Bank as a joint-stock bank in 1869 with the 50\% share of the Franco Ungarische Bank from Budapest. The bank's authorized capital was one million

Kukla, S., (1924), 29.

45 Arhiv Srbije, (1874): Zakon o hipotekanim založnicama Uprave fondova, Zbornik zakona, Zbornik 26, 67.

46 Arhiv Srbije, (1871): Zakon o okružnim štedionicama,Zbornik zakona, Zbornik 24, 97.

$47 \quad$ Ibid.

Vol. 13, № 3 2016: 1-20 
ducats divided into 25000 shares, each having the nominal value of 40 ducats. It started operations with paid-up capital of 120000 ducats, that rose to 200 000ducats in March 1873.

The main goal of the bank, according to the first Article of its Memorandum of Association, was "to help the development of trade and production in a country and to promote its trade relations with foreign countries". ${ }^{48}$ The range of bank's allowed operations was very wide - from banking to trade and construction. It could also take interests in industrial firms. Thus, the bank was of a universal type.

The Serbian government granted a special privilege to The First Serbian Bank. It was in form of a guarantee that no other foreign joint-stock company would be permitted to set up a bank in Serbia in the next five years ${ }^{49}$. However, the bank was not granted the privilege to issue notes, so it dealt only in coined money.

From the start, The First Serbian Bank mobilized majority of capital by raising loans with foreign banks. Domestic savings accounts were of a secondary importance. Contrary to its declared main goals, the bank invested heavily into various projects outside Serbia, possibly because of the strong influence of its foreign partner. Actually, its two biggest investments were made abroad. The first investment, in the amount of the half of its paid-up capital, was invested into a construction of a railroad connecting Budapest with Rijeka. The second big investment was made in 1870 into Forovich Shipping Society from Budapest. Comparing to these foreign investments, the bank's investments into domestic undertakings were negligible. Thus, the bank in practice exported capital from Serbia although there was a grave shortage of money and capital in the country.

When monetary and economic crisis broke in Austria-Hungary in the second half of 1872 and 1873, The First Serbian Bank faced liquidity problem due to cancellation of foreign loans and withdrawals of domestic savings. It addressed to the Serbian Ministry of Finance for an emergency assistance of 40000 ducats in November 1872 and got the half of the sum - 20000 ducats. However, it was not much of a help since withdrawals continued together with losses stemming from its foreign investments. Then, bank's shareholders saw that the only way out of the liquidity problem was in due repayments from its debtors and foreclosures. It turned out that its major debtors were the members of its Managing Board and bank employees who were not able to repay their loans on time. Faced with this situation, in January 1874 the bank publicly announced its intention of foreclosures but this also ended up without any results because small debtors refused to repay their debts before the major ones. Since all attempts for the rescue of the bank failed, it was liquidated in 1875. The great number of bank's shareholders and creditors never cashed their claims. Even the Serbian Ministry of Finance waited until 1887 to cash its claim of 20000 ducats.

$\begin{array}{ll}48 & \text { Cvijetić, L. (1964): Prva srpska banka, Istorijski glasnik 1-2, Beograd. } 99 . \\ & \text { Arhiv Srbije, (1869): Zakon o privilegijama Prve srpske banke, Zbornik zakona, Zbornik } 22 .\end{array}$ 
The special five-year monopolistic privilege given to The First Serbian Bank, to be the only bank with the foreign capital, thwarted the inflow of foreign capital into the other banks that were set up by 1873. In terms of capital, these purely domestic banks were small, with the exception of the Belgrade Credit House which initial authorized capital was 50000 ducats that was later raised to 100 000 ducats. In the middle of 1874, Belgrade Credit House took part in the rescue operation of The First Serbian Bank with the loan of 8000 ducats. In contrast to The First Serbian Bank, this bank successfully survived monetary and economic crisis of $1872-73$ period due to its cautious banking policy.

The downfall of The First Serbian Bank, the political instability and wars with Turks in 1876-7 broke the process of bank creation until after 1878.

In parallel with the creation of the first banks, Serbian authorities undertook series of monetary reforms which set off the process of regaining monetary sovereignty and disappearance of foreign coins from circulation. After more than four centuries, Serbia reestablished minting of national coins in 1868 by minting small copper coins. In 1873, The Act on Minting Serbian Silver Coin was passed, setting again that the silver dinar would be the Serbian national currency, proclaiming the dinar as the only legal tender in the Principality of Serbia and giving the right of minting exclusively to the State. As the national monetary unit, the dinar was defined at par with French franc. Just a few months after gaining political independence in 1878, the Act on Serbian National Currency was passed which replaced 1873 Act, but again defining the dinar as a national currency. The Act on Minting Serbian National Currency gave the right to mint national currency to the State and determined that dinar would be coined in gold, silver and copper. Thus, at the end of 1878, monetary conditions were ripe for the creation of the National Bank.

From the banking point of view, monetary reforms from 1868 to 1878 represented the end of the first and opening of the second stage of banking development in the $19^{\text {th }}$ century Serbia.

\section{Conclusion}

The development of Serbian banking from the beginning of the $19^{\text {th }}$ century until the First World War had two stages. The first stage ended in 1878 when Serbia became an independent state by the international agreement concluded at the Berlin Peace Conference.

In the first stage, the processes of step by step political liberation from the Ottoman rule, enlargement of the territory, increase of population, building of autonomous economic and institutional framework, and the growth of internal and foreign trade, all resulted in steady increase in demand for money and credits that finally led to the creation of the first banks in 1860s and 1870s. 
The beginning of credit operations was marked by the emergence of commercial credits, known as "veresija". Soon after the government of the vassal state of Serbia introduced organized credits from the state reserves (immovable crate) and later from various public funds, which were the church, orphan, school, widow and communal funds. By the end of this stage there were two types of proper banks: state banks and privately-owned banks. The state banks were of two types - one was the Administration of Funds and the other were five District Saving Houses. Out of the six private banks, the first one, The First Serbian Bank, lasted for only six years and was liquidated in 1875 due to a poor management.

Since the authorities of the vassal state of Serbia played a key role in preparing institutional framework for the banking operations and in organizing the first credit facilities, it could be argued that Serbian banking arose in the $19^{\text {th }}$ century as a result of both state-backed and growth-induced processes.

Political independence gained in 1878 and monetary reforms from 1868 to 1878 represented the end of the first and opening of the second stage of banking development in the $19^{\text {th }}$ century Serbia.

\section{Literature}

- Allen, Larry (2009): The Encyclopedia of Money, Second edition, ABC Santa Barbara, California; Denver, Colorado; Oxford, England.

- Arhiv Srbije, (1837): Zbornik zakona, Zbornik 30, Beograd.

- Arhiv Srbije,(1874): Zakon o hipotekanim založnicama Uprave fondova, Zbornik zakona, Zbornik 26.

- Arhiv Srbije, (1871): Zakon o okružnim štedionicama, Zbornik zakona, Zbornik 24.

- Arhiv Srbije, (1869): Zakon o privilegijama Prve srpske banke, Zbornik zakona, Zbornik 22.

- Cameron, R., Crips, O., Patrick, Hugh T. and Tilly, R.(1967): Banking in the Early Stages of Industrialiization, Oxford University Press, London.

- Cvijetić, L. (1970): Kreditiranje iz državne kase do formiranja Uprave fondova, Finansije XXV, broj 9-10.

- Cvijetić, L. (1965): Pokušaji osnivanja prvih banaka u Srbiji, Finansije broj 1-2.

- Cvijetić, L. (1964): Prva srpska banka, Istorijski glasnik 1-2, Beograd.

- Dugalić, V.(1999): Narodna banka 1884-1941, Jugoslovenski pregled, Beograd.

- Dva veka razvoja Srbije - Statistički pregled, (Two Centuries of Serbian Development - Statistical Review), (oktobar 2008): Republički zavod za statistiku, Beograd

- Glomazić, M. (1933): Istorija državne hipotekarne banke 1862-1932, Narodna misao, Beograd. 
- Gnjatović, D., Dugalić, V., Stojanović, B. (2003): Istorija nacionalnog novca, Sineks, Beograd.

- Gnjatović, Dragana (2013): Privilegovana agrarna banka Prilog istoriji poljoprivrednog kredita Srbije 1836-1947, Udruženje banaka Srbije, Beograd.

- Građanski zakonik za Kraljevinu Srbiju, (1891): u Beogradu, štampa i izdanje Kralj.srpske drž. Štamparije

- Jovanović, Slobodan (1925): Ustavobranitelji i njihova vlada (1838-1858), drugo dopunjeno izdanje, Izdavačka knjižarnica Napredak, Beograd.

- Kalić, J. (2001): Srbi u poznom srednjem veku, Službeni list SRJ, Beograd.

- Kindleberger, P. Charles, (1987): Financial History of Western Europe, George Allen \&Unvin, London.

- Kukla, S. (1924): Razvitak kreditne organizacije u Srbiji (do svetskog rata), Komisiona naklada, Zagreb.

- Milić, D. (1998): Privredne prilike u Srbiji na početku XIX veka, Zbornik, Narodni muzej Niš, broj 5, Niš.

- $\quad$ Milić, D. (1959): Trgovina Srbije 1815-1839, Nolit, Beograd.

- Milić, D. (1981): Nepokretna kasa, Istorijski institut, Poseban otisak iz mešovite građe, Knjiga 9, Beograd.

- Milić, Dr D. (1994): Monetarno-kreditni sistem u privredi Srbije početkom $X X$ veka, in: Srbija u modernizacijskim procesima XX veka, Institut za noviju istoriju Srbije, Beograd.

- Petrović, J. (1933-34): Veoma retki srpski srednjovekovni grošići iz sela Malo Boljince kod Vlasotinaca, Starinar VIII-IX.

- Petrović, M. (1901): Finansije i ustanove obnovljene Srbije do 1842, knjiga I, Štampano u državnoj štampariji Kraljevine Srbije.

- Stanojević, S. (2008): Istorija srpskog naroda, Logos Art, Beograd.

- Tadić, J. (1968): Privreda Dubrovnika i srpske zemlje u prvoj polovini XV veka, Zbornik filozofskog fakulteta, X-1.

- Taranovski, Teodor (2002) Istorija srpskog prava u Nemanjićkoj državi, Lirika, d.o.o, Beograd.

- Vučo, Dr N. (1955): Privredna istorija Srbije, Naučna knjiga, Beograd.

- White, E. (1998): Were Banks special Intermediaries in Late Nineteenth Century America, Federal Reserve Bank of St. Louis, May/June. 


\section{APPENDIX}

Figure 1 Enlargement of Serbia 1815-1919

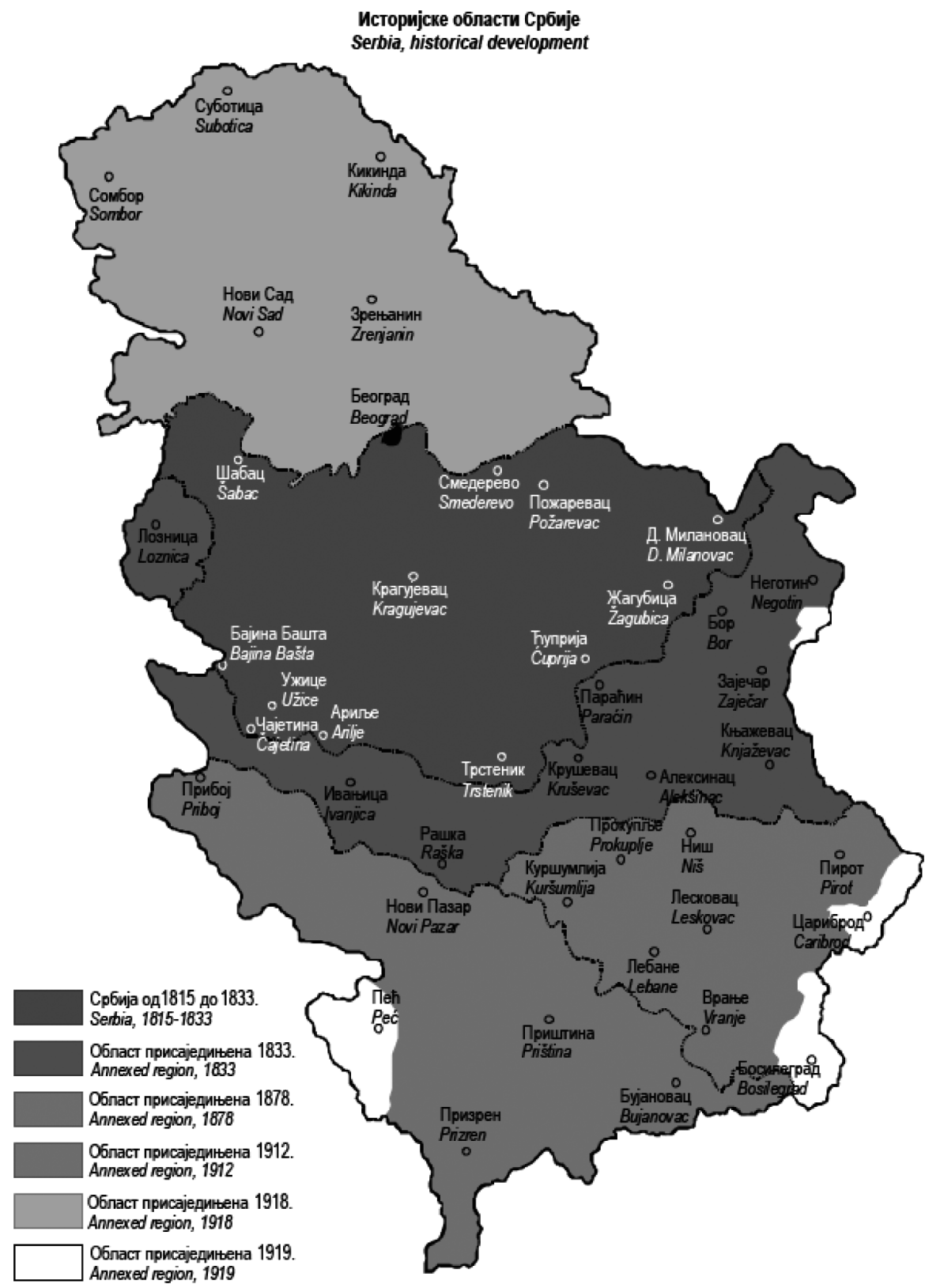

Izvor: Dva veka razvoja Srbije - Statistički pregled, (Two Centuries of Serbian Development Statistical Review), (oktobar 2008): Republički zavod za statistiku, Beograd, p. 22. 


\section{Prof. dr Biljana Stojanović}

Geoekonomski fakultet, (Fakultet za međunarodnu ekonomiju), Univerzitet Džon Nezbit, Beograd

\section{NASTANAK I RAST SRPSKOG BANAKARSTVA DO PRVOG SVETSKOG RATA Prvi deo:}

\section{Stvaranje preduslova za nastanak srpskog bankarstva do 1878}

Razvoj srpskog bankarstva tokom 19. veka je bio postepen process koji je imao dve faze sa prekretnicom u 1878. godini, kada je Srbija postala nezavisna država medunarodnim ugovorom zaključenim na Mirovnoj konferenciji u Berlinu. U prvoj fazi, do 1878. godine, vazalna država Srbija je stvarala neophodne političke, ekonomske i institucionalne preduslove za razvoj bankarstva što je dovelo do stvaranja prvih oblika organizovanog kredita i prvih banaka. Na kraju ove faze, postojale su dve vrste banaka: državne $i$ privatne. Budući da su vlasti vazalne države Srbije imale ključnu ulogu u pripremi institucionalnog okvira za bankarsko poslovanje, kao $i$ u stvaranju pvih organizovanih kredita, moglo bi se reći da je srpsko bankarstvo u 19. veku nastalo kao rezultat dva procesa - aktivne uloge države i privrednog rasta.

Ključne reči: bankarstvo, organizovani krediti, kamatne stope, zelenaštvo, uplaćeni kapital, vazalna država Srbija 